Abstract AB0870 Table 1. Number of discharges with a principal diagnosis of stroke, by age group and sex, reported to HIPE, 2007-2017

\begin{tabular}{|c|c|c|c|c|c|c|c|c|c|c|c|}
\hline & 2007 & 2008 & 2009 & 2010 & 2011 & 2012 & 2013 & 2014 & 2015 & 2016 & 2017 \\
\hline \multicolumn{12}{|l|}{ Age Group } \\
\hline $0-29$ years & 191 & 193 & 112 & 93 & 136 & 118 & 90 & 94 & 92 & 97 & 89 \\
\hline 30-34 Years & 62 & 53 & 62 & 65 & 57 & 65 & 56 & 54 & 59 & 56 & 57 \\
\hline 35-39 Years & 93 & 107 & 119 & 68 & 82 & 75 & 82 & 63 & 98 & 93 & 81 \\
\hline 40-44 Years & 141 & 153 & 134 & 162 & 152 & 163 & 125 & 123 & 131 & 144 & 158 \\
\hline 45-49 Years & 215 & 169 & 170 & 205 & 232 & 214 & 198 & 193 & 176 & 249 & 201 \\
\hline 50-54 Years & 315 & 293 & 277 & 284 & 279 & 299 & 254 & 307 & 289 & 309 & 295 \\
\hline 55-59 Years & 338 & 386 & 395 & 417 & 393 & 345 & 372 & 415 & 386 & 398 & 413 \\
\hline 60-64 Years & 467 & 560 & 523 & 508 & 500 & 504 & 492 & 489 & 559 & 565 & 505 \\
\hline 65-69 Years & 566 & 578 & 585 & 600 & 631 & 643 & 662 & 657 & 667 & 677 & 766 \\
\hline 70-74 Years & 730 & 709 & 763 & 677 & 712 & 682 & 749 & 782 & 821 & 838 & 778 \\
\hline 75-79 Years & 886 & 890 & 935 & 937 & 889 & 926 & 845 & 867 & 909 & 862 & 915 \\
\hline 80-84 Years & 967 & 902 & 975 & 924 & 860 & 959 & 878 & 944 & 912 & 935 & 927 \\
\hline 85-89 Years & 648 & 695 & 728 & 699 & 703 & 717 & 705 & 695 & 666 & 697 & 702 \\
\hline 90 Years and over & 278 & 315 & 325 & 363 & 342 & 388 & 354 & 352 & 401 & 411 & 412 \\
\hline \multicolumn{12}{|l|}{ Sex } \\
\hline Male & 2,988 & 3,066 & 3,107 & 3,087 & 3,071 & 3,174 & 3,032 & 3,198 & 3,368 & 3,413 & 3,499 \\
\hline Female & 2,909 & 2,937 & 2,996 & 2,915 & 2,897 & 2,924 & 2,830 & 2,837 & 2,798 & 2,918 & 2,800 \\
\hline Total & 5,897 & 5,897 & 5,897 & 5,897 & 5,897 & 5,897 & 5,897 & 5,897 & 5,897 & 5,897 & 5,897 \\
\hline
\end{tabular}

Disclosure of Interests: Rada Gancheva: None declared, Atanas Koundurdjiev: None declared, Galina Nikolova: None declared, Mariana Ivanova Goycheva Speakers bureau: Abbvie, Pfizer, UCB, Novartis, Todor Kundurzhiev: None declared, Zlatimir Kolarov: None declared, Veselina Gadjeva: None declared

DOI: 10.1136/annrheumdis-2019-eular.1952

\section{AB0870 IS THE INCIDENCE OF GOUT SIMILAR TO OTHER RISK FACTORS IN PATIENTS PRESENTING WITH STROKE OR MYOCARDIAL INFARCTION?}

Aine Gorman, Gillian Fitzgerald, Finbar Barry O'shea. St. James's Hospital, Rheumatology, Dublin, Ireland

Background: Gout is a common form of inflammatory arthritis. The prevalence of gout in Europe is between $0.9-2.5 \%$ with rates as high as $4 \%$ reported in Ireland.1 Studies have suggested gout as a risk factor in patients presenting with myocardial infarction (MI) and stroke (CVA). However the incidence gout in patients presenting to hospital with MI or CVA in Ireland has not previously been assessed.

Objectives: The aim of this study was to assess the incidence of gout in patients presenting with CVA and MI in Ireland. A further objective was to explore if the incidence of gout is similar to other risk factors such as hypertension, diabetes mellitus and dyslipidemia in Irish patients presenting with CVA and MI.

Methods: The Hospital In-Patient Enquiry Scheme ( HIPE) was used to identify patients admitted with stroke or myocardial infarction from 62 acute public hospitals in Ireland from January 2007 until December 2017. HIPE is a national database which records coded hospital admission and demographic, clinical and administrative data on discharges from, and deaths in, acute public hospitals nationally.2 Discharges are coded using the International Statistical Classification of Diseases and Related Health Problems, Tenth Revision, Australian Modification (ICD-10-AM), Australian Classification of Health interventions (ACHI), Australian Coding Standards (ACS), 8th Edition. Age, gender and number of patient admissions with $\mathrm{Ml}$ or CVA with gout, diabetes, hypertension, peripheral vascular disease (PVD) and hyperlipidemia were recorded.

Results: From 2007 until 2017, 64,867 were admitted with a diagnosis of CVA in Ireland. The age and gender of patients admitted with a principal diagnosis of CVA are outlined in Table 1. 70,628 patients were admitted with MI.

In the CVA population, $14.5 \%$ of patients had diabetes. Incidence of gout in patients with $\operatorname{CVA}(0.7 \%)$ was similar to patient with the risk factors of hyperlipidemia $(0.91 \%)$ and PVD $(0.94 \%)$.

The incidence of gout in the $\mathrm{Ml}$ group $(0.5 \%)$ was lower when compared to the stroke group $(0.77 \%)$. The presence of diabetes as a risk factor ( $6.7 \%)$ was significantly higher compared to gout $(0.5 \%)$ in patients admitted with myocardial infarction. Chart one outlines the incidence of each risk factor in patients discharge with a primary diagnosis of MI in Ireland between 2007 and 2017

Conclusion: The incidence of gout in patients presenting with CVA or Ml in Ireland was low compared to other risk factors including diabetes. In patients presenting with $\mathrm{Ml}$ then incidence of gout is lower than in patients presenting with CVA.

\section{REFERENCES}

[1] Richette $\mathrm{P}$ et al, 2016 updated EULAR evidence-based recommendations for the management of gout, Ann Rheum Dis 2017;76:29-42.

[2] Moloney ED, et I Do consultants differ? Inferences drawn from hospital inpatient enquiry (HIPE) discharge coding at an Irish teaching hospital Postgraduate Medical Journal 2005;81:327-332.

Chart 1:Incidence of risk factors in patients with a diacharge diagnosis MI, reported to HIPE, 2007-2017

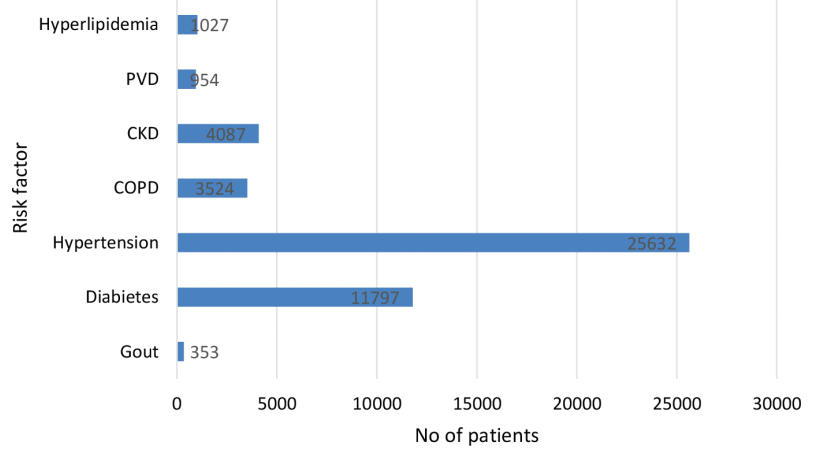

Figure 1

Disclosure of Interests: None declared

DOI: 10.1136/annrheumdis-2019-eular.1302

\section{AB0871 ASSESSMENT OF THE KIDNEYS AND URINARY TRACT DYSFUNCTIONS THAT INCREASE THE RISK OF DEVELOPING CHRONIC KIDNEY DISEASE IN PATIENTS WITH GOUT BASED ON COMPLEX RENAL SCINTIGRAPHY}

Margarita Gromova ${ }^{1}$, Vladimir Tsurko ${ }^{1}$, Anna Kashkadayeva ${ }^{2}$,

Svetlana Averinova ${ }^{2}$, Andrey Aliokhin ${ }^{3} .{ }^{1}$ Pirogov Russian National Research Medical University, Department of Faculty Therapy, Moscow, Russian Federation; ${ }^{2}$ N.N.Blokhin National Medical Research Center of Oncology, Laboratory of Radioisotope Diagnostics, Moscow, Russian Federation; ${ }^{3}$ Group of companies Tekon, Moscow, Russian Federation

Background: In $40 \%$ of cases patients with gout can develop gouty nephropathy, the "kidney mask" of gout. The newest version of the technology for systemic examination of nephrourological status based on complex renal scintigraphy (SENS-CRS) has been developed at the "N.N Blokhin National Medical Research Center of Oncology». SENS-CRS at the lowest doses of radiation ( $0.6 \mathrm{mSv}$ per adult) allows for an in-depth differential analysis of dysfunctions of the renal parenchyma, upper and lower urinary tract which increase the risk of chronic kidney disease (CKD) development. 